УДК $338.26 « 313 »: 351: 338.49(477)$

DOI https://doi.org/10.32837/apfs.v0i32.1039

\author{
B. A. Ліпкан \\ доктор юридичних наук, професор, \\ докторант відділу правових проблем політологіі \\ Інституту держави і права імені В. М. Корецького Національної академії наук України
}

\title{
СТРАТЕГІЯ ДЕРЖАВНОЇ ІНФРАСТРУКТУРНОЇ ПОЛІТИКИ УКРАЇНИ 3 ПОЗИЦІЙ НОРМАТИВІЗМУ
}

Постановка проблеми. Державна інфраструктурна політика (ДІФСП) як система широкомасштабних комплексних цілеспрямованих заходів компетентних суб'єктів ще й зараз перебуває на етапі свого формування і унормування. Нині через застосування маніпулятивних технологій система державного управління і політико-правова практика перенасичені фейками, симулякрами, спотвореною інформацією, яка загалом формує підгрунтя для реалізації чужих національних інтересів на території України, встановлення контролю над об'єктами стратегічної інфраструктури. Аналогічна ситуація складається і у сфері реалізації стратегії ДІФСП. Відтак у рамках саме теоретичної науки, зокрема політології, постає наукове завдання щодо коректного дослідження цієї стратегії, передусім із застосуванням наукової методології.

Аналіз публікацій. Багатоплановість обраної для дослідження теми зумовлює звернення до ряду аспектів. По-перше, це питання методології науки. В цьому напрямі $є$ важливими розробки таких вчених, як М. Буроменський, С. Бобровнік, В. Горбатенко, Ю. Власов, О. Ганьба, С. Даниленко, С. Дністрянський, Є. Ерліх, Г. Кельзен, Б. Кістяківський, I. Кресіна, А. Коваленко, М. Козюбра, М. Костицький, О. Кушнір, Є. Макаренко, О. Мережко, І. Настасяк, М. Ожеван, Н. Оніщенко, Б. Парахонський, М. Рижков, Ю. Римаренко, В. Сіренко, О. Скрипнюк, В. Старосольський, О. Стойко, Ю. Шемшученко, В. Явір, А. Яковець та інші.

По-друге, це наукові розвідки щодо різних аспектів формування стратегії державної інфраструктурної політики України Д. Бірюкова, М. Бутка, О. Єрменчука, Г. Зубка, С. Кондратова, О. Кравченко, О. Криницької, О. Лощихіна, Д. Нестерової, В. Новикової, І. Рекуненка, І. Садловської, А. Стояновського, О. Суходолі, С. Теленика, Л. Федулової, І. Чуницької та інші.

Виділення не вирішених раніше частин загальної проблеми. Якщо стосовно методів правового регулювання суспільних відносин у сфері інфраструктурної політики, зарубіжного досвіду можна констатувати про наявність значної кількості публікацій, то стосовно формування теорії інфраструктурної політики, зокрема гносеологічного її компонента, передусім наукової методології, публікацій обмаль.
Тим більше, навіть формування такого концепту, як «державна інфраструктурна політика» нині не вважається консенсусним. Відтак використання наукової методології матиме подвійне значення: з одного боку, воно спрямовано на досягнення проголошених цілей в статті, а з іншого - сприятиме подовженню наукової дискусії щодо остаточного і парадигмального ставлення до формування та існування окремого виду політики - державної інфраструктурної політики. Так само застосування наукової методології сприятиме розумінню та усвідомленню сучасного політико-безпекового дискурсу, в рамках якого доцільно говорити не просто про політику, а про необхідність формування та реалізації саме стратегї державної інфраструктурної політики.

Постановка завдання. У зв'язку з цим мета статті полягає у розкритті змісту стратегії державної інфраструктурної політики із використанням концепції нормативізму.

Досягненню поставленої мети сприятиме розв'язання таких завдань:

1) з'ясування дуалізму сущого і належного;

2) накреслення абрисів розуміння стратегії як політико-правової і безпекової практики;

3) обгрунтування необхідності використання принципу справедливості під час формування і реалізації стратегії державної інфраструктурної політики.

Виклад основного матеріалу дослідження. Методологічною основою нормативізму стала неокантіанська теорія про дуалізм сущого і належного.

За такого підходу нормативізм інтерпретує стратегію ДІФСП (як політико-безпекову практику) як сферу належного, а не сущого, обмежуючись вивченням формальної сторони процесів реалізації цієї стратегії. Нормативізм виступає за очищення формування цієї стратегії як окремого виду політико-правової та безпекової практики діяльності уповноважених суб'єктів. Через це в рамках нормативізму презюмується ідея щодо очищення цієї стратегії від інших, не властивих цій діяльності напрямів. Вельми цікавим $є$ те, що нормативізм не протиставляє стратегію ДІФСП і силу, відтак унаочнюється завдання щодо розвитку інфраструктурного потенціалу та формування тактики і стратегії протидії інфраструктурним 
війнам, реалізації інфраструктурних інтересів в тому числі й за межами держави, включаючи космос і кіберпростір.

Відтак, зважаючи на свою універсальність, фактор сили є іманентним у межах формування та реалізації стратегії ДІФСП.

У межах цієї стратегії чітко передбачається використання сили, інших інструментів, у тому числі стратегічних комунікацій, гібридних війн, чітко визначеним у законодавстві колом суб'єктів забезпечення безпеки стратегічної інфраструктури для формування необхідних умов і безпосередньої реалізації пріоритетних національних інтересів.

Ми постійно наголошуємо на тому, що стратегія ДІФСП має розглядатися саме як політико-правова практика, через це навіть сам факт функціонування національної системи інфрастурктури і відповідна практика мають бути закріпленими у відповідному НПА, що однозначно формує умови для ствердження про юридичний характер діяльності суб'єктів цієї системи і наявність юридичних підстав для застосування сили та інших дієвих засобів впливу для реалізації національних інтересів.

Методологія авторського бачення, відповідно до предмета дослідження, Ірунтується на розробленій автором цієї статті новаторській авторській пут ькришерѓт ёо "кчерут тёо "с уйкрё:

1) геостратегія сучасної Української держави;

2) стратегія державної інфраструктурної політики України;

3) стратегічне управління, яке включає механізми стратегічного планування, прогнозування, передбачення та стратегічних комунікацій на основі концептуальної моделі стратегічної архітектури, стратегічного мислення, свідомості і культури;

4) стратегічні цінності;

5) стратегічні національні інтереси з урахуванням стратегічних національних пріоритетів;

6) стратегічна інфраструктура;

7) стратегічна правотворчість.

Причому події останніх років, передусім із протидією пандемії у 2020 році, яскраво продемонстрували, що кожна країна дбає винятково лише про власні національні інтереси, не цураючись при цьому застосування можливостей розвідувального товариства, заходів примусу, залякування, інших заходів з метою отримання преференційного доступу до вакцин задля реалізації інтересів лише власної країни. Нашу думку підтверджує i український фахівець з проблем безпеки стратегічної інфраструктури О. Кушнір, відзначаючи, що роль спеціальних служб у захисті об'єктів критичної інфраструктури, одна 3 найголовніших. Це пов'язано насамперед з тим, що саме на спеціальні служби покладено функцію недопущення дестабілізації національних систем, в тому числі національної кредитно-банківської системи та страхового ринку; а також протидія втручанню у стабільне функціонування систем, в тому числі кредитно-банківської системи та системи державних фінансів, використанню їх на шкоду національним інтересам України [6].

Через це закріплений принцип про домінування міжнародного законодавства над внутрішнім має бути значно скоригований.

Так, наприклад, ми не можемо погодитись із думкою I.В. Міми, про те, що «ефективність впливу міжнародного права на національну правову систему залежить від повноти відображення та 3'ясування закономірностей міжнародного розвитку із урахуванням внутрішніх особливостей національного права, а також від стану розробленості правових засобів держави, за наявності яких відбувається ефективний регулятивний вплив на суспільні відносини» [11, с. 184].

Автор дуже серйозно плутає причину і наслідок: внутрішне право має відображати закономірності функціонування та розвитку суспільних відносин на засадничій підставі творення та збереження національних цінностей з метою реалізації національних інтересів. Своєю чергою норми міжнародного права, в яких ці закономірності не відображені, не можуть покращити внутрішнє право, тобто вони не сприяють досягненню цілей стратегії розвитку країни, а відтак не можуть бути визнані прийнятними та такими, що можуть поліпшити стан правового регулювання тих чи інших суспільних відносин.

Ці всі так звані «прописні істини та правила» міжнародного права були повністю знецінені, починаючи з 8 серпня 2008 року (на жаль, це не дата початку Олімпіади, а дата неоголошеної і безкарної війни Росії проти Грузії), коли система міжнародного правопорядку зазнала незворотних i деструктивних змін.

А події 2020 року з пандемією, державним егоїзмом, біологічним шовінізмом окремих країн і в 2021 році із суттєвою мілітаризацією міжнародних відносин чисельними збройними конфліктами між суб'єктами, які б мали забезпечувати та гарантувати світову безпеку, сформували іншу реальну, а не книжкову, та не побоюся цих невисокопарних слів «буквоїдську істину щодо примату міжнародного права»: держави, що чітко дотримуються міжнародного права, виявилися безпорадними перед глобальними i реальними загрозами власній незалежності, суверенітету, що сприяло втраті інфраструктурного потенціалу та формуванню на довгостроковій основі енергетичної залежності, в тому числі втраті контролю над стійким розвитком інфраструктурного ландшафту, дестабілізації найбільш важливих систем життєзабезпечення і взагалі існуванню системи національних цінностей.

3 метою реалізації стратегії ДІФСП має бути сформованадостатнясистеманормативно-правового 
регулювання суспільних відносин у цій сфері, яку можуть підсилити міжнародно-правові механізми захисту прав і свобод людини і громадянина (якщо вони не суперечать національному законодавству).

Геостратегія сучасної України базується передусім на реалізації національних цінностей:

- ми не можемо думати і дбати про європейську безпеку, допоки ми не забезпечимо власну безпеку;

- ми не маємо виправдовуватися ані перед ким за ті методи і способи, інструменти та взагалі стратегію і політику загалом, які ми використовуємо і реалізуємо задля забезпечення реалізації власної геостратегії в контексті забезпечення державного суверенітету, відновлення територіальної цілісності та Української державності загалом, зокрема забезпечення національної безпеки і реалізації безпекоінфраструктурної політики;

- жодна з країн - гарантів безпеки України (згідно з Будапештським меморандумом) насправді не надала цих гарантій, передусім йдеться про Францію, Німеччину, Китай. А Росія взагалі вчинила акт агресії. Тому жодна з країн-гарантів, яка не надала суттєвої і реальної, а не задекларованої допомоги, втратила цей статус, відтак не має жодного права вказувати Україні, яким чином їй забезпечувати власну національну безпеку, реалізовувати власну інфраструктурну стратегію. Будьякі спроби таких коментарів з боку офіційних осіб перелічених держав можуть вважатися спробою втручання у внутрішні справи нашої держави;

- ми не можемо думати, наприклад, про енергетичну незалежність Європи, допоки ми не реалізуємо власний інфраструктурний потенціал у цій сфері і не сформуємо достатні умови для гарантованого енергопостачання власної нації потрібною кількістю енергоносіїв тощо.

Ще одне. Президента країни обирає на голосуванні народ України, який є єдиним джерелом влади. Відтак народ обирає того, хто має створити збалансовану систему реалізації національних інтересів людини, суспільства і держави. Народ обирає Президента для управління ним в інтересах народу, тобто самого себе.

Народ України не обирає Президента України для:

- реалізації національних інтересів інших країн або взагалі обслуговування інтересів транснаціональних корпорацій (міжнародних організацій, наднаціональних структур, фінансових установ тощо);

- реалізації міжнародних договорів, які суперечать природному праву, а також внутрішньому законодавству України, принципам вітчизняного законодавства, а також засадничим його положенням і традиціям право- і державотворення;

- нав'язування чужих, навіть більше - деструктивних та конфронтаційних і антагоністичних смислів;
- імплементації та підтримки не властивих нашій політичній системі практик і правовій системі норм, в тому числі й соціальних, культурних, зразків поведінки, які не відповідають національним цінностям, традиціям та укладу життя українців;

- обслуговування інтересів олігархів і забезпечення олігархічного консенсусу.

Ми є автохтонною нацією, а тому маємо власні багатотисячолітні традиції, власний уклад життя, самобутність, культуру, антропогенний та сакральний ландшафти. До речі, маємо те, чого багато із «сучасних вчителів та глашатаїв європейських цінностей» на міжнародній арені взагалі не можуть мати за визначенням. Так, можемо визнати, що наша нація не завжди існувала у формі держави, водночас вона завжди мала свій стрижень, основу, цінності, системоутворюючі елементи, які саме і не дали їй згинути в історії.

Саме тому у своїй роботі я відхожу від суто теоретичних і фактично міфічних міркувань, зокрема пріоритетності міжнародного права над внутрішнім законодавством, які сьогодні вже абсолютно не відповідають дійсності, реаліям міжнародних відносин і взагалі не є справжніми. Так, наприклад, нехтуючи національними інтересами:

- України - Німеччина ухвалила рішення у 2021 році щодо «Північного потоку-2» відповідно до власних національних інтересів. Оскільки за транспортування газу до Свропи Україна отримувала близько 3 мільярдів доларів щорічно, то Німеччина з Росією завдали шкоди Україні саме на цю суму (сюди слід додати індекс інфляції, втрачену вигоду, а також інші не завжди вимірювані у числовому вираженні параметри). Ніякі санкції не допомогли, а обіцянки, як здебільшого це відбуваються, виявилися порожніми. Відтак суто теоретично з позицій геостратегії вважати нині Німеччину нашим союзником у протидії Росії є безпідставним і стратегічно помилковим та шкідливим;

- Франції - Австралія у жовтні 2021 року розірвала багатомільярдний договір на будову дизельних підводних човнів і підписала його зі США;

- багатонаціональної коаліції держав - США влітку 2021 року вивели свої війська з Афганістану, що спричинило суттєві людські втрати, матеріальні втрати в особливо великих розмірах, передачу технологій і високотехнологічного озброєння третім країнам.

I таких прикладів можна наводити безліч (це і Китай, і Африка та Азія), тому закликаю сучасних дослідників міжнародних відносин і взагалі представників політико-правової думки у власних дослідженнях відтворювати не бажані і міфічні уявлення про дійсні міжнародні відносини (які вони почасти черпають з підручників минулого), а відображати справжній стан та ті реалії, в яких опинилось людство і в якому напрямі воно має рухатися з урахуванням викладеного вище 
надалі. Іншими словами: відображати результати власних проведених досліджень, а не форматувати дійсність під алгоритми та теоретичні матриці і теорії, викладені в підручниках минулого; власне, просто здійснювати справжню наукову і пошукову дослідницьку діяльність.

Наука має визначати контури майбутнього на підставі того, що маємо сьогодні. Право має виступати інструментом реалізації стратегії ДІФСП, а не навпаки. Право за таких обставин закріплює нові правовідносини, водночас у межах окреслених цілей в результаті реалізації стратегії як політико-безпекової практики.

Буду відвертий: настав час realpolitik - час відмови від порожніх балачок, пафосних і демагогічних закликів, нудних та убогих за змістом ортодоксальних теоретичних дискусій, онтологічний дискурс яких є відлунням минулого, яке застрягло в головах та змістовних позиціях наукових праць апологетів старої політичної школи. Наразі політика дедалі більше зміщується в сферу стратегій, а відтак ця сфера вимагає більш прагматичного ставлення як до розуміння та осягнення реальних національних інтересів, так і прагматичного розуміння ставлення до нашої держави інших країн, їх реальної, а не декларованої та публічно, але бездоказово, озвученої дієвої допомоги.

Наприклад: допомога лише США Афганістану за офіційними даними з 2001 по 2019 рік склала близько 822 млрд доларів. Ця сума, однак, не враховує витрати у Пакистані, який США використовує як базу для афганських операцій [12]. Відтак за наявними лише у відкритих джерелах інформації даними було витрачено понад 1 трильйон доларів! Можна порівняти з рівнем допомоги Україні і дійти власних висновків.

Зокрема, резонує нашій позиції думка професора М.В. Буроменського, який відзначає, що з позицій дуалістичної теорії національне та міжнародне право розглядаються як дві самостійні правові системи, що мають індивідуальні механізми правового регулювання суспільних відносин, а отже, і різний правопорядок. Прихильники дуалізму вважають, що хоча ці правові системи не позбавлені можливості взаємодії, норми міжнародного права не в змозі здійснювати дієвий вплив у напрямі нормативного впорядкування та систематизації правопорядку в межах національного механізму правового регулювання суспільних відносин, і навпаки, норми національного права не можуть виконувати регулятивних функцій у міжнародно-правових відносинах [10, с. 61-62].

Солідаризуючись із цією думкою, підкреслю, що в усіх своїх публікаціях і науковій і практичній діяльності відстоював позицію щодо верховенства національного права.

Зокрема, також я свого часу підкреслював, що наразі актуалізується проблема формування нової концепції права, яка відображатиме реальний період існування і тенденції розвитку світу: період агресивної глобалізації: час утвердження відносин сили, коли провідним країнам світу, об'єднаним до єдиного військово-політичного блоку НАТО, вкрай потрібна стабільна правова основа здійснення силових акцій із встановлення контролю над природними та іншими ресурсами інших країн (так звані операції з примушення до миру, забезпечення прав і свобод людини, гуманітарна інтервенція, боротьба з кібервійнами, формування наднаціональних структур тощо).

Саме тому поки прибічники теорії інституціоналізму намагаються переконати певних представників права у своїх прагненнях щодо подальшого утвердження «верховенства права», насправді відбувається порушення головного атрибута права, що загалом суперечить природі права як такого, оскільки правлячі світом організації по-новому тлумачать і реалізують цей принцип: †зкхъузкт цчзуA" ме" йуфус уиуќ " фххезе. За цих умов тлумачення тероризму має рамковий контекст, натомість тлумачення екстремізму і тим більше - встановлення відповідальності за вчинення екстремістської діяльності - має багато правових суперечностей, що і надає змогу за допомогою права реалізовувати власні політичні стратегії, котрі іноді суперечать національним інтересам [8].

Водночас дієвість норм міжнародного права в механізмі правового регулювання національної правової системи залежить передусім від того, яким чином вони сприятимуть збереженню і творенню національних цінностей і реалізації національних інтересів, але не навпаки!

На проблему конкретизації статусу міжнародних договірних норм у національній правовій системі відзначає і український академік Ю.С. Шемшученко, акцентуючи на необхідності визначення засад співвідношення міжнародних договорів i національних нормативно-правових актів як джерел права [2, с. 391].

Отже, коріння дискусії сягають у багатолітню історію, натомість наразі настав час для чіткої відповіді на одвічні питання: в чому полягає юридична сила міжнародних принципів і норм і як слід будувати відносини з тими державами, які не дотримуються і порушують їх?

Звичайно, що можна і далі продовжувати говорити про розвиток інтеграційних процесів, подальше розроблення адаптаційної взаємодії міжнародного та національного права, посилення співпраці у сфері енергетичної незалежності та розроблення спільної інфраструктурної політики тощо. Утім, у політичній практиці держави, що керувалися передусім загальнонаціональною ідеологією, національними пріоритетами, виявилися набагато гнучкішими і більш стійкими до нестабільності, 
протидії пандемії коронавірусу, зміни сил безпеки, центрів формування світової політики і взагалі до трансформаційних змін та утворення різноманітних секторальних політико-безпекових конфігурацій (наприклад: AUKUS, QUAD).

Зокрема, конфліктні інтереси Туреччини та Росії у Сирії не завадили цим двом країнам запустити у 2020 році спільний газогін «Турецький потік» 3 обсягом потужності прокачки газу 30 млрд кубометрів на рік і отримувати спільну вигоду від цього, постачаючи газ до Греції, Угорщини та інших країн. Навіть більше, Туреччина не визнає анексію Криму, утім, ультимативно вимагає не називати дрони, куплені в Туреччині, за допомогою яких українські військові знищують ворожі сили російських окупантів, турецькими [13]. Відтак світ дедалі більше і головне - глибше - крокує в бік фрагментарності та секторальності, ворожої упередженості. I такі тенденції також слід ураховувати під час формування стратегії ДІФСП України.

Тож, за таких умов виникає закономірне запитання: чим ми маємо керуватись? Тим, що має конкретний реальний та відчутний результат, чи тим, що кимось нав' язується і не відповідає національним інтересам?

Думається, що відповідь на це питання потрібно шукати у системотворчому і засадничому документі - Конституції України.

Оскільки найвищу юридичну силу і норми прямої дії містить Конституція України, стратегія ДІФСП має будуватися з огляду на національні інтереси, задля творення і збереження національних цінностей. Якщо міжнародні договори або інші рішення суперечать цьому принципу, вони мають бути визнаними нікчемними і не можуть бути імплементованими до національної правової системи.

Гарлонізація законодавства має похідний характер від гармонізації цінностей: спочатку потрібно гармонізувати цінності та інтереси, а вже потім законодавство. Порушення логіки призводить до закладення конфліктогенності у соціальну систему, а відтак відчутні дестабілізаційні коливання наперед унеможливлюють формування достатньої та ефективної системи реалізації стратегії державної інфраструктурної політики України.

Воднораз можуть виникнути такі питання: чим виступають національні системи безпеки стратегічної інфраструктури інших країн або ж взагалі більш високого порядку? Як має узгоджуватись стратегія ДІФСП окремої країни з аналогічними практиками інших країн?

Якщо брати ідеальну модель, то надійне, безпечне та стійке функціонування систем національної інфраструктури та відповідних їм стратегій є позитивним фактом. Адже в глобалізованому світі небезпека в одній системі породжує і сприяє реалізації небезпеці в іншій. Відтак ефективне функціонування системи забезпечення інфраструктур- ної безпеки, а також взагалі стратегї ДІФСП, є важливим компонентом стратегій інших країн. Наприклад, проблеми з енергопостачанням в одній країні напряму впливають на функціонування усієї національної системи інфраструктури іншої країни. Отже, природним є вироблення спільних засад розроблення даних стратегій з урахуванням національної специфіки і можливостей держав щодо контролю і збереження інфраструктурного суверенітету.

Виходячи з наведеного, розуміння призначення стратегії ДІФСП, норлативізм у поєднанні із дуалістичною і лоністичною теоріяли сучасної юриспрудениї щодо розкриття засад взаємодії національного та міжнародного права [3, с. 4], постулює, що стратегія ДІФСП може вважатися дієвим компонентом безпекоінфраструктурної міжнародної політики через те, що вона резервує для міжнародного співтовариства як спільної соціальної системи, об'єднаної консенсусними цінностями та принципами та інтересами, використання сили та будь-якого інструментарію впливу (гібридні технології, розумна сила, стратегічні комунікації, штучний інтелект, космічна зброя, нейромережі тощо), встановлюючи монополію на їх застосування.

У цій інтерпретації стратегія ДІФСП виступає дієвим механізмом встановлення примусової справедливості, рівноваги, балансу і порядку, тобто такого стану, за якого можлива максимальна реалізація інфраструктурного потенціалу кожної країни в узгоджених суб'єктами міжнародних відносин рамках реалізації національних інтересів.

При цьому слід особливо звернути увагу на централізацію і децентралізацї під час реалізації стратегії ДІФСП.

Так, у межах окремо узятої країни можна виділити конкретних суб'єктів (державних і недержавних), яким делеговані державою повноваження щодо реалізації цієї політики, зміст якої полягає у створенні умов для гарантованого і безперебійного надання життєво важливих послуг i реалізації життєво важливих функцій.

На мій погляд, приналежність чи управління об'єктом стратегічної інфраструктури до приватних операторів чи суб'єктів не є підставою для втрати ініціативного управління саме державою всією системою національної інфрастурктури. Таким чином, у контексті реалізації стратегії ДІФСП України доцільно твердити про иентралізацію повноважень у сфері інфраструктурної політики і формування окремого центрального органу виконавчої влади.

Стосовно міжнародної безпекоінфраструктурної політики, то тут механізм вжиття відповідних заходів набагато складніший. Насамперед він зумовлений різними правовими режимами та взагалі підходами до віднесення тих чи інших об'єктів саме до об’єктів стратегічної інфрастурктури. 
Так само слід відверто говорити і про те, що в окремих державах взагалі така категорія не виділяється, а держава зосереджує свою увагу саме на можливості надання соцієтальних функцій. Відтак, загалом резюмуючи, відмітимо, що різність тлумачення і розуміння цих процесів наперед ускладнює узгоджену діяльність багатьох держав, тим більше із різними правовими системами, у сфері реалізації спільної стратегії.

Радше за даного випадку говорити про можливість і корисність розроблення окремих інфраструктурних секторальних / рамкових стратегій окремих країн, котрі будуть спрямовані на досягнення певного рівня стійкості тих чи інших окремих сфер життєдіяльності і надання в їх рамках окремих функцій із чітко визначеним інструментарієм, який може бути розроблено в межах окремих тактик. Відтак адекватно глокалізаційним (не плутати із глобалізаційними) тенденціям формуються відповідні інфраструктурні стратегії. Таким чином, я прагну дотримуватися логіки свого дослідження, спираючись на отримані власне мною наукові результати.

Отже, колективне управління сферою інфраструктури (міжнародними суб’єктами) є, на мою думку, не оптимальним, адже за даного випадку втрачається єдність і керованість цієї системою.

3 іншого боку, иентралізація на вжиття заходів щодо реалізації стратегії ДІФСП є неможливою, таким чином, постає потреба у децентралізації цих повноважень між країнами - учасницями цієї системи. Проте цей процес також не є легким, бо значно ускладнюється процес прийняття рішення про застосування тих чи інших силових засобів або вжиття конкретних заходів.

Прикладом тому може бути агресія проти Іраку у березні 2003 року, коли одноголосно у безапеляційному порядку США розпочали агресію проти Іраку, тоді як країни - учасниці системи загальноєвропейської безпеки, передусім Німеччина, Франція, Бельгія, висловилися категорично проти таких дій з боку США. Однак, ураховуючи повільність у прийнятті рішень, а тим більше у їх втіленні у життя, ця система так і не вжила конкретних заходів щодо реалізації власного рішення.

Така ж ситуація спостерігалася із будовою в обхід України газопроводу «Північний потік - 2», який причинив суттєву матеріальну шкоду Україні, водночас, через недалекоглядну інфраструктурну політику, створив значні умови для залежності європейських клієнтів від режиму постачання російського газу. Зокрема, Франк Гофман вважає, що «позиція Берліна щодо "Північного потоку - 2" - ознака неспроможності зовнішньої політики Німеччини. Вона розколола Захід. Німецько-російське будівництво газогону під патронатом московського грошового станка під назвою „Газпром” розкололо Європу та Захід. Німецька канцлерка Ангела Меркель - відповідальна за шкоду, завдану ї̈ багаторічною аргументацією, що йдеться, мовляв, про суто економічний проєкт. Його реалізація відбувається всупереч волі Свропарламенту, всупереч тиску з боку найближчих друзів - Франції, держав Скандинавії та Балтії і передусім Польщі. I зрештою, всупереч волі Конгресу США» [4].

Ба більше, цей експерт відзначає: «У першу чергу Берлін має попрощатися з геополітичною наївністю останніх років та разом із друзями в Парижі відстоювати спільні європейські інтереси. Це означає в тому числі повною мірою використовувати газовий кран у німецькому Любміні на березі Балтійського моря. Адже це не просто якийсь технічний елемент ланцюга в суто економічному проєкті, а геополітичний владний інструмент. Він працює у двох напрямах кран можна або відкрутити, або закрутити» [4].

Звідси можна дійти деяких проміжних висновків:

- no-перше, об'єкти стратегічної інфраструктури виступають інструментами геостратегії. Це аксіома, яка нині не має піддаватися сумніву або зайвим наївним узагальнюючим теоретизуванням. Економічна доцільність ніколи не переважить геостратегічної корисності і прагматичності.

- nо-друге, інфраструктура в контексті реалізації геостратегії виступає механізмом відстоювання не лише національних, але й спільних європейських цінностей. Тобто інфраструктура та відповідна до неї державна політика, стратегії (інший концептуально-когнітивний та практично-діяльнісний інструментарії) формують достатні умови для реалізації геостратегії.

- no-mpeтє, наголошується на тому, що інфраструктурний потенціал може виступати владним інструментом, тобто наголошується про застосування парадигми етатизму через звернення до першості державної політики як основоположної у цій. Навіть більше, опис інфраструктурного потенціалу відбувається за допомогою політологічної термінології.

Також за даного випадку можу вказати на різницю між стратегіями ДІФСП різних країн. Ба більше, звертаю увагу на те, що якщо в окремій державі існує централізований механізм реалізації стратегії ДІФСП, то у системах колективного управління спільним інфраструктурним комплексом цей механізм здебільшого є децентралізованим.

Таким чином, система управління інфраструктурою на наднаціональному рівні є більш складною порівняно зі стратегією ДІФСП конкретної країни. Передусім це пов'язано із тим, що значно уповільнюється механізм оцінки та ідентифікації тих чи інших загроз інфраструктурі згідно з локальними безпековими політиками, в тому числі й формування адекватних механізмів їх локалізації, зважаючи на наявні ресурси, в тому числі нормативне регулювання.

Утім, не можна не підкреслити намагання централізації управління в рамках окремих колективних систем безпеки, зокрема НАТО, ОБСЕ, через створення у цих системах спеціальних координаційних штабів, інноваційно-інвестиційних фондів, завданням яких би було координувати 
3 урахуванням національних інтересів країн учасниць відповідної стратегії реалізації спільної інфраструктурної політики, включаючи космічну сферу і використання штучного інтелекту.

Норлативістська теорія дотримується моністичного погляду на співвідношення між стратегіями ДІФСП різних країн, оскільки інтерпретує їх як єдине ціле, пірамідальну, ієрархічно організовану структуру. У цій моделі інфраструктурний потенціал системи більш низького рівня черпає свої додаткові спроможності із інфраструктурних систем більш високого рівня. За даного випадку можна казати про іманентну інтегративну властивість стратегії інфраструктурної політики, яка прагне весь час до самовдосконалення. Причому адекватним когнітивним інструментом для реалізації цієї політики виступає моністична концепція права.

Зауважимо, що нормативістський метод викликав значну критику 3 боку філософів. Так, наприклад, Б.А. Кистяківський вважав абсолютно помилковим протиставляти суще належному в сфері онтології, бо безперервний рух емпіричного буття, який проявляється і різних видах і формах, органічно включає в себе як суще, так і належне (цит. за [9, с. 29]).

Утім, А. Шопенгауер порізнює суще (світ в уявленні) і справжнє буття (світ волі). Причому така тенденція щодо протиставлення сущого і належного є притаманною філософії Ф. Ніцше і К’єркегора і взагалі домінує у феноменології та екзистенціалізмі. Саме некласична концепція буття в найбільш розвиненій формі представлена у феноменології та екзистенціалізмі, в межах яких відбувається тяжіння суб'єктивізму, за якого, на відміну від матеріалістичних та ідеалістичних концепцій, визначення буття відбувається через свідомість та існування людини. Відтак у межах онтології визначають найважливіші аспекти трактування буття в сучасній науковій картині світу [7], які можуть пристосувати і до предмета свого дослідження.

1. Буття постає переважно в диналічнолу, а не статичнолу вигляді, світ і буття визнається процесуальнили за основною їх тендениі$\epsilon ю$, відтак найбільш адекватним інструментом за умови динамічності буття виступають у межах формування геостратегії сучасної України окремі стратегії державної політики, зокрема стосовно сфери інфраструктури - стратегія державної інфраструктурної політики.

2. Буття постає як систела у діалектичнолу зв'язку та взаєлодї̈ «всього з усіл», через що розвиток запропонованої мною нової інтерпретації концепції інфраструктурного ландшафту, включаючи і космічний, і сакральний, і кіберпростір тощо, $€$ важливим напрямом формування релевантної сучасним реаліям діалектики стратегії ДІФСП.

3. До сучасної наукової картини світу входить рівнево-ієрархізована будова проявів буття (мікро-, макро- та мегапроцеси ). На всіх рівнях діють свої особливі закони, тендениї, якісні характери- стики. Зазначене уможливлює припускати і враховувати той факт, що стратегія ДІФСП окремої країни або окремі її фрагменти можуть бути частиною стратегій країн вищого технологічного укладу або з більшим інфраструктурним потенціалом.

4. Багаторівневість проявів буття делонструє себе ще й еволюиійно. Сучасна наука лає підстави стверджувати, що нижчі форли світових процесів, з одного боку, постають грунтол длявищих, а з іншого - входять до вищих як їх складові елеленти. Отже, еволюиійний процес рухається у напрялі дедалі тотальнішого прояву глибинних характеристик буття. У иьолу аспекті розвиненіші форли сутнього є більш делонстративні, більш розгорнуті щодо виявлення форл буття, ніж нижчі. Це означає, що розроблення стратегії ДІФСП є проєкцією майбутнього нашої держави, досягнувши якого, постане проблема у розробленні нових стратегій для подальшого еволюційного розвитку як соціальної системи та інфраструктурного потенціалу, так і держави в рамках геостратегії нашої держави як базової та гомеостатичної системи концептуальних поглядів на ефективне їі функціонування.

5. Сучасна наука розглядає форли проявів буття лище в аспекті органічної бності та неподільності об’єкта і суб’єкта Якщо раніше иі поняття розлежовували, то тепер людина як суб'єкт постає органічною часткою світу. Відтак стратегія ДІФСП (як політико-безпекова практика) є інструментом коеволюції людини і світу, гармонійного розвитку інтересів людини, окремих націй i держав відповідно до загальної коеволюційної та гуманістичної концепції, водночас стратегія ДІФСП як нормативний акт є органічним компонентом національної правової системи в межах реалізації геостратегії сучасної України.

Подальшого дослідження і своєї належної інтерпретації в контексті порівняння сущого і належного в межах окремих наукових розвідок потребують концепції: монізму; дуалізму; плюралізму; субстанціалізму; реїзму; організмізму; механіцизму; динамізму; статизму.

У цьому аспекті щодо поєднання нормативізму і монізму в юриспруденції і політології також слід звернути увагу і на такі категорії, як diєвість $i$ значилість. Адже нормативізм за цього випадку, на відміну від дескриптивного підходу, надає нового змісту поняттю справедливість, яке не дорівнює поняттю рівність. Адже будь-яка країна, яка, наприклад, здійснює ворожі дії щодо іншої країни, встановлює контроль над інфраструктурним комплексом або окремими об'єктами інфраструктури чи окремими сферами інфраструктурної політики, з позицій власного національного законодавства захищає власний суверенітет; 3 позицій іншої держави - вчинює акт війни або акт агресії / анексії. Саме тому за першого і другого випадку можемо говорити про diєвість права в аспекті відповідності діяльності певних суб'єктів національному праву. 
3 позицій значилості і справедливості оцінка діяльності цих суб'єктів буде іншою. Відтак дескриптивний підхід, фактично з позицій формально-юридичних, може обгрунтувати інфраструктурну війну як необхідний і законний напрям реалізації державної політики. Власне, так відбулася втрата значної кількості об'єктів стратегічної інфраструктури Україною через діяльність Росії: з позицій Росії (позитивізм) - все законно; з позицій України і міжнародного співтовариства все незаконно.

Висновки. Відтак унаочнюється висновок про те, що модерна інтерпретація і застосування нормативізму у практиці міжнародних відносин призводить до юридичного догматизму і юридичної схоластики, жорсткого прагматизму й утилітаризму юридичної практики.

Водночас з позицій нормативізму, яка тяжіє до справедливості, стратегія ДІФСП має розглядатися крізь призму значимості для реалізації національних інтересів. Відтак можемо підтримати думку В.В. Костицького, який відзначив, що «учений повинен користуватися натуралістичною, психологічною, феноменологічною, діалектичною, екзистенціоналістською, структуралістською, герменевтичною (і лише потім - нормативістською) методологією або творити на їх підгрунті власну методологію наукового юридичного пізнання» [5, с. 28].

Наголосимо: справедливість не дорівнює рівності. Справедливість нами трактується як критичний оціночний масштаб політико-моральної здатності до мислення і втілення значимих як для окремої нації, так і для людства загалом усвідомлених актів.

Додаткову аргументацію нашій позиції можемо надибати в юридичній царині. Зокрема, відзначимо, що одним із проявів верховенства права $€$ те, що право не обмежується лише законодавством як однією з його форм, а включає й інші соціальні регулятори, зокрема, норми моралі, традиції, звичаї тощо, які легітимовані суспільством i зумовлені історично досягнутим культурним рівнем суспільства. Всі ці елементи права об'єднуються якістю, що відповідає ідеології справедливості, ідеї права, яка значною мірою дістала відображення в Конституції України. Зазвичай справедливість - одна з основних засад права, $є$ вирішальною у визначенні його як регулятора суспільних відносин, одним із загальнолюдських вимірів права. Зазвичай справедливість розглядають як властивість права, виражену, зокрема, в рівному юридичному масштабі поведінки й у пропорційності юридичної відповідальності вчиненому правопорушенню [1].

Саме ця позиція Конституційного Суду України надає можливості нам наголосити на тому, що закон може бути дієвим, але несправедливим, обмежувати права і свободи інших людей, націй тощо. За цих умов право є ширшим за закон. Акцентування нами на дослідженні та усвідомленні порізнення сущого і належного є вкрай важливим не лише для нашого подальшого дослідження, адже почасти застосування формально-юридичного та дескриптивного підходів у різних вимірах публічної риторики призводить до використання маніпулятивних технологій i формування хибної думки щодо справедливості тих чи інших дій. Саме це і призводить до конфліктогенності суспільства, обгрунтування тих чи інших дій поза контекстом справедливості.

Нормативізм в органічному поєднанні із лінгвістичною та логічною методологіями має залишатися в практичній політології та юриспруденції і може бути корисним передусім як для наукового коментування діяльності політичних інститутів або законодавчих чи підзаконних актів, так і для формування обріїв та горизонтів не лише дієвості, а й практичної їх значимості та справедливості в межах політичних відносин в аналізованій сфері державної політики.

\section{Jimepamypa}

1. Верховенство права. Каталог юридичних позииій Конституиійного Суду України (за рішеннями та висновками). URL: https://ccu.gov.ua/storinkaknygy/34-verhovenstvo-prava.

2. Джерела конституційного права України / відп. ред. : Ю.С. Шемшученко, О.І. Ющик. Київ : Ін-т держави i права ім. В.М. Корецького НАН України, 2010. 710 с.

3. Козюбра М.I. Тенденції розвитку джерел права України в контексті європейських правоінтеграційних процесів. Наукові записки Національного університету «Києво-Могилянська академія». Т. 26 : Юридичні науки. Київ, 2004. С. 3-9.

4. Коментар: «Північний потік-2» - шкода, заподіяна Анґелою Меркель. URL: https://www.dw.com/ uk/komentar-pivnichnyi-potik-2-shkoda-zapodiianaangeloiu-merkel/a-58602045.

5. Костицький В.В. Нормативізм як методологія юриспруденції. Науковий вісник Наиіональної академії внутрішніх справ. 2014. № 4. С. 17-29.

6. Кушнір О.В. Кримінологічні аспекти формування державної системи захисту об'єктів критичної інфраструктури. URL: https://goal-int.org/kriminologichniaspekti-formuvannya-derzhavnoyi-sistemi-zahistu-obyektiv-kritichnoyi-infrastrukturi/.

7. Лекційні матеріали. Тема 3: Онтологія. Філософія: мультимедійний навчальний посібник / B.M. Кравець та ін. URL: https://arm.naiau.kiev. ua/books/filosofia-30012017/lection/lec3.html.

8. Ліпкан В.А., Лобода А.М. Підвалини формування нової концепції права в контексті протидії екстремізму. URL: https://goal-int.org/pidvaliniformuvannya-novoi-koncepcii-prava-v-kontekstiprotidii-ekstremizmu/.

9. Мережко А.А. Введение в философию международного права. Гносеология международного права. Киев : Юстиниан, 2002. 192 с.

10. Міжнародне право : навчальний посібник / за ред. М.В. Буроменського. Київ : Юрінком Інтер, 2006. $336 \mathrm{c}$. 
11. Міма І.В., Іванюк Н.В. Порівняльно-правовий аналіз взаємозв'язку національного та міжнародного права в умовах інтеграційних процесів. Juris Europensis Scientia. 2020. Вип. 4. С. 181-185.

12. Скільки грошей США та НАТО витратили на війну в Афганістані. URL: https://www.bbc.com/ ukrainian/features-58230178.

13. Туреччина вимагає від України припинити використовувати фразу «турецький Байрактар». URL: https://www.eurointegration.com.ua/ news $/ 2021 / 10 / 31 / 7129678 /$.

\section{Анотаиія}

Ліпкан В. А. Стратегія державної інфраструктурної політики України з позицій нормативізму. - Стаття.

Діапазон наукової проблеми обраної теми статті зумовлює використання різноманітних методів дослідження. Логіка дослідження передбачає встановлення в межах неокантіанської традиції дуалізму категорій суще і належне, з'ясування потенціалу нормативізму для додаткового обгрунтування принципу верховенства права, а також обґрунтування категорій diєвicmb, значилість і справедливість. На підставі концепції нормативізму аналізуються сучасні політичні тенденції, які впливають на формування геостратегії сучасної України, зокрема на стратегію розроблення державної інфраструктурної політики.

Контекст статті усіляко просякнутий концепцією Realpolitik, яка реально збільшує синергетичний потенціал теоретичних знань та підвищує праксеологічний рівень політологічної науки. В умовах трансформації під впливом глобалізаційних і регіональних чинників сучасної міжнародної системи та формування нового світового порядку стратегія державної інфраструктурної політики України презентована крізь політико-безпековий і правовий дискурс.

Відповідно подається три напрями дослідження: 1) стратегія як політична практика; 2) стратегія як нормативно-правовий акт; 3) стратегія як безпековий напрям діяльності держави. Подана модель виступає інтегральним результатом екстраполяції методів політичного аналізу, правового регулювання, безпекознавства та моделювання на сферу процесів в інфраструктурній сфері на засадах методології побудови геостратегії сучасної Української держави.

Науково обгрунтовано використання сили, іншого сучасного та інноваційного інструментарію, в тому числі стратегічних комунікацій, гібридних війн, чітко визначеними політичними інститутами, які формують та реалізують стратегію державної інфраструктурної політики для формування гарантованих Конституції України і забезпечених інфраструктурним потенціалом умов для безпосередньої реалізації стратегічних національних інтересів.

Науково доведено, що нормативізм, в органічному поєднанні із лінгвістичною та логічною методологіями, має залишатися в практичній юри- спруденції і може бути корисним як для наукового коментування законодавчих чи підзаконних актів, так і для формування обріїв та горизонтів дієвості і практичної їх значимості та справедливості.

Ключові слова: геостратегія, нормативізм, суще і належне, сакральний ландшафт, державна інфраструктурна політика, інфраструктурний потенціал, національні цінності, національні інтереси, стратегічні пріоритети, геостратегія сучасної України.

\section{Sammary}

Lipkan $V$. A. Strategy for state infrastructure policy of Ukraine from the perspective of normativism. Article.

The scope of the scientific problem under consideration of the article determines the use of various research methods. The logic of the study involves establishing, under the neo-Kantian tradition of dualism, of the categories of things in existence and proper, clarifying the potential of normativism for further justification of the rule of law and the categories of effectiveness, significance and justice. Based on the concept of normativism, the author analyzes the modern political tendencies which influence the formation of geostrategy of modern Ukraine, in particular, strategy for the state infrastructure policy.

The context of the article is imbued with the concept of Realpolitik, which truly advances the synergetic potential of theoretical knowledge and increases the praxeological level of political science. Amidst transformation under the impact of globalization and regional factors of the modern international system and the formation of a new world order, the Strategy of State Infrastructure Policy of Ukraine is presented through political, security and legal discourse.

Therefore, the research lines are put forward: 1) strategy as a political practice; 2) strategy as a statutory act; 3) strategy as a security direction of the state. This model is an integral result of extrapolation of methods of political analysis, legal regulation, security studies and modeling to the infrastructure processes on the basis of the methodology of building the geostrategy of the modern Ukrainian state.

It is scientifically substantiated the use of force, other modern and innovative tools, including strategic communications, hybrid wars well-defined by political institutions that form and implement the strategy of state infrastructure policy to form conditions for direct realization of strategic national interests guaranteed by the Constitution of Ukraine and supported by infrastructure potential.

It is scientifically proved that normativism, in organic combination with linguistic and logical methodologies, should remain in practical jurisprudence and can be useful both for scientific commenting of laws or regulations and the formation of horizons of effectiveness and their practical significance and fairness.

Key words: geostrategy, normativism, existing and proper, sacred landscape, state infrastructure policy, infrastructure potential, national values, national interests, strategic priorities, geostrategy of modern Ukraine. 